\title{
DAS RESTRIÇÕES ESTATAIS AO DIREITO FUNDAMENTAL À LIVRE INICIATIVA
}

\author{
STATE RESTRICTIONS ON THE FUNDAMENTAL \\ RIGHT TO FREE ENTERPRISE
}

Ana Paula da Silva Liberalino ${ }^{1}$

Marcelo Lauar Leite ${ }^{2}$

\begin{abstract}
RESUMO: A livre iniciativa - ou liberdade econômica - apesar de estar expressamente prevista como fundamento da Ordem Econômica Brasileira, no caput do artigo 170 da Constituiçấo Federal, é, por vezes, mencionada - pela doutrina e jurisprudência - como um princípio. Além desse embaraço de conceitos jurídicos, há pouco desenvolvimento científico acerca do que é a livre iniciativa e, consequentemente, baixa garantia desse direito constitucional. Indaga-se: o que é a liberdade econômica e quais prerrogativas individuais esta compreende? Em face de quê ou de quem se exerce tal direito constitucional? Este possui limitaçôes? Se sim, em quais hipóteses? Para responder tais questōes, essa pesquisa investigará o conceito de livre iniciativa, o qual será perseguido através da exposiçăo de aspectos históricos e evolutivos da noçăo de liberdade econômica, à luz do ordenamento jurídico brasileiro e comparado. Analisar-se-á as prerrogativas que a livre iniciativa compreende, ou seja, quais săo os direitos individuais por ela abrangidos. Em seguida, averiguar-se-á a natureza jurídica da liberdade econômica no sistema normativo do Brasil e, por fim, em quais hipóteses tal direito constitucional pode ser limitado pelo Estado.
\end{abstract}

PALAVRAS-CHAVE: Livre iniciativa; conteúdo; natureza jurídica; direito constitucional; restriçấo estatal.

ABSTRACT: Free enterprise - or economic freedom - despite being expressly provided as the foundation of the Brazilian economic order, in the caput of artigo 170 of the Federal Constitution, is sometimes mentioned - by the doctrine and jurisprudence - as a principle. In addition to this embarrassment of legal concepts, there is little scientific development of what is free enterprise, and, therefore, low guarantee to this constitutional right. The question proposed: what is economic freedom and which individual prerogatives comprises this? In the face of what or who is exercised this constitutional right? This has limitations? If yes, in which cases? To answer these

\footnotetext{
$1 \quad$ Graduanda em Direito pela Universidade Federal Rural do Semi-Árido (UFERSA). Membro dos grupos de pesquisa da UFERSA: Teoria Geral do Direito e Estudos Clássicos (GTDEC) e Relaçóes jurídicas e atividade econômica. anplib@gmail.com

2 Advogado. Professor Assistente-A do Curso de Direito da UFERSA. Bacharel e Mestre pela UFRN. Doutorando em Ciências Jurídicas pela Universidade de Coimbra. marcelo.lauar@ufersa.edu.br
} 
questions, this research will investigate the concept of free enterprise, which will be pursued through the exhibition of historical and evolutionary aspects of the notion of economic freedom in the light of the Brazilian and compared law. It will analyze the prerogatives that the free enterprise comprises, that is, what are the rights of individuals covered by it. Then, it will be to ascertain the legal nature of economic freedom in the regulatory system in Brazil and, finally, in which cases such constitutional right may be restricted by the state.

KEY-WORDS: Free enterprise; content;legalnature; constitutionalright;State restrictions.

\section{CONSIDERAÇÕES INICIAIS}

A Constituiçấo Federal de 1988 consagra a livre iniciativa como razâo de ser da Ordem Econômica brasileira - ao lado da valorizaçăo do trabalho humano. Ademais, seus valores sociais săo tidos como fundamento da República, afetando, por conseguinte, a interpretaçăo das normas constitucionais e infraconstitucionais (PETTER, 2013, p. 57). ${ }^{3}$

A livre iniciativa é desdobramento da liberdade humana (GRAU, 2014, p. 199), a qual tem por expressáo a autonomia privada ou capacidade de autogoverno - em seu sentido amplo ${ }^{-}$, ou seja, a concepçăo de que o indivíduo é livre para fazer as escolhas concernentes à sua vida particular. Esse espaço de possibilidades concedido à criatividade humana é considerado o motor da sociedade (MARTINS FILHO, 2010, p. 290).5 Destarte, năo possui menor importância em relação à economia, uma vez que é através da vontade criadora dos indivíduos que se assegura o desenvolvimento econômico de uma naçăo.

Como fundamento, a livre iniciativa irradia diversos corolários nos quais deve prevalecer a liberdade do sujeito de direito. A acepçăo mais comum - e, portanto, mais desenvolvida pela doutrina e jurisprudência - da livre iniciativa equivale à liberdade de empreender economicamente (LEITE, 2013, p. 05.), ${ }^{6}$ a qual consta no artigo 170, parágrafo único, 7 da Carta Magna.

Nâo obstante sua importância constitucional, a livre iniciativa nâo tem um conceito jurídico bem definido, em razâo da pouca exploraçăo doutrinária e

3 Coadunando com esse entendimento, cf.: TAVARES, 2011. p. 237, e BARROSO, 2009, pp. 49-50.

4 Consoante Daniel Sarmento, a autonomia privada, entendida em seu sentido amplo, é a capacidade do sujeito de direito de determinar seu comportamento, e compreende desde suas escolhas existenciais àquelas concernentes aos negócios jurídicos. Faz ainda a observaçăo de que alguns autores utilizam uma acepçáo mais restrita, relacionando-a apenas ao âmbito contratual. (2006, p. 222.).

5 No mesmo sentido, grassa Lafayete Josué Petter, ao afirmar que a liberdade é "razăo avaliatória do processo de desenvolvimento - quanto mais liberdade, mais desenvolvimento - mas também é razăo de eficácia do desenvolvimento - a realizaçăo do desenvolvimento depende da livre condiçăo de agente das pessoas." (PETTER, 2008, p. 85.).

6 Nessa pesquisa, o autor se refere à obra de Rogério Roberto Gonçalves de Abreu.

"Art. 170. A ordem econômica, fundada na valorizaçấo do trabalho humano e na livre-iniciativa, tem por fim assegurar a todos existência digna, conforme os ditames da justiça social [...]

Parágrafo único. É assegurado a todos o livre exercício de qualquer atividade econômica, independentemente de autorizaçăo de órgăos públicos, salvo nos casos previstos em lei." (Grifo nosso). 
jurisprudencial do assunto. Por vezes, esse direito é erroneamente conceituado como princípio, natureza esta que năo mais subsiste no contexto econômico delineado pela Constituiçấo Federal. Dessa forma, năo săo claros os contornos da livre iniciativa, e, em vista disso, há pouca segurança jurídica aos titulares das garantias provenientes de tal liberdade.

Indaga-se: o que é a livre iniciativa e quais prerrogativas individuais esta compreende? Em face de quê ou de quem se exerce tal direito constitucional? Em quais hipóteses cabe a sua restriçâo? Visando a resposta a essas questōes, esta pesquisa investigará o conceito de livre iniciativa, o qual será perseguido através da exposiçăo de aspectos históricos da noçâo de liberdade econômica, bem como por meio da análise do que esta compreende, ou seja, quais sâo os direitos individuais abrangidos pela livre iniciativa. Em seguida, averiguar-se-á a natureza jurídica dessa liberdade econômica no sistema normativo do Brasil. Por fim, circunscrever-se-á as margens e limites da restriçáo estatal a esse direito fundamental.

Para fins desta pesquisa, os termos livre iniciativa e liberdade econômica seráo considerados sinônimos. Por sua vez, utilizar-se-á a expressăo autonomia privada em suas acepçóes ampla - designando a capacidade do sujeito de direito de fazer escolhas relativas à sua vida particular - ou restrita - remetendo-se à autonomia negocial.

\section{O CONCEITO DE LIVRE INICIATIVA}

\subsection{Breve relato histórico}

A atividade humana expressa-se em diversas áreas da vida social: na economia, política, artes, ciências, entre outras. Para tanto, o indivíduo necessita de liberdade. Em outras palavras, é preciso que seja concedido ao sujeito um espaço no qual possa desenvolver suas habilidades para criar e executar suas ideias independentemente (BADENI, 2004, p. 322).

Essa ideia de autonomia, de vontade criadora do ser, foi de crucial importância para a origem dos atos comerciais, nos quais, pode-se afirmar, apareceram os primeiros traços característicos do que hoje compreendemos por livre iniciativa, embora tais aspectos estivessem restritos, inicialmente, ao âmbito contratual.

As primeiras práticas de comércio estăo intimamente ligadas à necessidade. É esta que, à medida que cresce, dá luz ao espírito de especulaçâo e negociaçâo para fornecer satisfaçôes entre os indivíduos. Isso foi possível a partir do momento no qual a sociedade passou a ser mais do que famílias isoladas - cujas pequenas necessidades podiam ser auto-atendidas -, pois estas, ao se unirem, formaram uma comunidade de deveres e interesses recíprocos. Nasceu a divisăo do trabalho e, com esta, o comércio, ou seja, a troca de excedentes entre os trabalhadores para que fosse possível adquirirem 0 necessário (MASSÉ, 1861, pp. 4-5.).

Note-se que esse interesse em satisfazer e criar novas necessidades, assim como a inclinaçāo natural do homem para aumentar seus prazeres em prol de seu bem-estar, foi e é o principal motivo de suas açōes (MASSÉ, 1861, p. 5.). Logo, a essa vontade se deve năo só a origem mercadológica, como também a propulsăo ao seu desenvolvimento, tal 
como é reconhecido por nossa Constituiçăo, enquanto esta reserva prioritariamente aos particulares a exploraçáo da atividade econômica - conforme consta em seu artigo $173 .^{8}$

Por conseguinte, é possível indicar a autonomia privada - entendida em seu sentido amplo, ou seja, na ideia de que o indivíduo é livre para tomar decisóes relativas à sua vida pessoal, desde aspectos existenciais a patrimoniais ou contratuais - como a primeira expressâo da livre iniciativa - compreendida enquanto poder dos particulares de criar e desenvolver uma atividade econômica, disciplinando-a juridicamente conforme seus interesses (AMARAL NETO, 1986, p. 228.) -, principalmente no que concerne ao contrato.9

Ao lado disso, desenvolveu-se um dos atributos fundamentais do homem que possibilita o desenvolvimento de sua criatividade humana, assim como o progresso social: a propriedade (BADENI, 2004, p. 605.). De acordo com Francisco dos Santos Amaral Neto (AMARAL NETO, 1986, p. 229.), a partir do desenvolvimento comercial e dos centros mercantis na idade medieval e moderna, a atividade econômica passou a ser considerada autônoma. A partir dessa fragmentaçăo, formaram-se dois núcleos distintos, porém, relacionados: (i) a propriedade, como direito subjetivo e atributo essencial do ser, e (ii) a liberdade iniciativa, enquanto poder dos particulares de desenvolverem uma atividade econômica organizada para o fim da produçâo ou da troca de bens e serviços.

Logo, enquanto ideia autônoma, a livre iniciativa possui relaçōes próprias com diversos aspectos nos quais deve estar presente a autonomia humana: trata-se dos seus corolários ou facetas da livre iniciativa, os quais permitem uma melhor compreensăo, e, consequentemente, maior garantia dessa liberdade jurídica.

\subsection{Corolários ou facetas constitucionais da livre iniciativa}

A Constituiçấo de 1988 consagrou, no caput do artigo 170,10 a livre iniciativa como causa ou razâo de ser da ordem econômica (PETTER, 2013, pp. 50-51.) - ao lado da valorizaçăo do trabalho humano. Năo obstante, os valores sociais de tal liberdade econômica săo tidos como um dos fundamentos da República, 11 afetando, portanto, a interpretaçăo de todo o ordenamento jurídico brasileiro.

A livre iniciativa, enquanto liberdade jurídica (BADENI, 2004, p. 324), nâo se manifesta isoladamente, mas em um contexto de normas com relaçóes particulares entre si (BOBBIO, 1995, p. 19). Logo, possui íntima ligaçăo com outros direitos expressos constitucionalmente, sem os quais năo se pode falar em liberdade econômica, pois esta pressupóe aqueles.

8 "Art. 173. Ressalvados os casos previstos nesta Constituiçăo, a exploraçăo direta de atividade econômica pelo Estado só será permitida quando necessário aos imperativos da segurança nacional ou a relevante interesse coletivo, conforme definidos em lei."

9 O contrato é, como informa Teresa Ancona Lopez, instrumento da autonomia privada. (2007, p. 10.).

10 Cf. nota de rodapé $n^{\circ} 5$.

11 "Art. 1o A República Federativa do Brasil, formada pela uniăo indissolúvel dos Estados e Municípios e do Distrito Federal, constitui-se em Estado Democrático de Direito e tem como fundamentos:

$[\ldots]$

IV - os valores sociais do trabalho e da livre iniciativa;

$[\ldots] . "$ 
Dessa forma, com o objetivo de compreender o significado da proposiçâo da livre iniciativa, ${ }^{12}$ torna-se necessário elencar quais sâo os seus corolários constitucionais. Em outros termos, é preciso analisar quais săo os direitos imprescindíveis para o entendimento - e consequentemente, melhor concretizaçăo - da liberdade econômica dos indivíduos.

A partir de uma interpretaçăo sistemática, Marcelo Lauar Leite (2013, p. 5) ${ }^{13}$ propóe que a livre iniciativa dos indivíduos possui quatro facetas constitucionais: as liberdades de empreendimento, associaçâo, contrato e açâo profissional.

A primeira faceta - prevista no artigo 170, parágrafo único, ${ }^{14}$ da Constituiçâo Federal - mais comumente designada por liberdade de empresa (CARVALHOSA, 1972, p. 115), trata-se do direito ao exercício de qualquer atividade econômica, independentemente de autorizaçăo de órgăo público, ressalvadas as limitaçôes legais e as que provenham de outros interesses tutelados pelo ordenamento jurídico. ${ }^{15}$

Por sua vez, a liberdade de associaçâo, direito fundamental expressamente previsto no artigo $5 .^{\circ}$, XVII a XX,16 da Lei Maior, diz respeito à livre reuniâo estável e permanente de pessoas, objetivando a defesa de interesses comuns, independentemente de autorizaçăo, desde que seus fins năo afrontem a Constituiçấo, a ordem e os bons costumes (BASTOS, 1999, p. 205). Dessa forma, cabe ao indivíduo a autonomia de organizar-se da maneira que julgue ser mais adequada à prestaçâo de seus serviços (TAVARES, 2011, p. 237), possuindo os direitos de: (i) elaborar os seus atos constitutivos; (ii) escolher as pessoas incumbidas de gerenciar a associaçâo; (iii) ser livre na sua gestâo; e (iv) associar-se ou nâo (BASTOS, 1999, pp. 205-206).

Garante-se também a liberdade de contrato - ou seja, a realizaçăo de negócio jurídico por meio de vontades livremente convencionadas, visando a produzir efeitos reciprocamente vinculantes -, uma vez que esta é inerente ao exercício de todas as facetas constitucionais da livre iniciativa. Năo há qualquer empreendimento, exercício profissional ou associaçăo que nâo faça uso do contrato como instrumento para

12 Segundo Norberto Bobbio, proposiçăo é um conjunto de palavras que possuem um significado em sua unidade, cabendo ao jurista interpretá-la para alcançar a sua significaçăo jurídica. (2005, p. 74.). Dessa forma, torna-se pertinente buscar o significado da proposiçâo na qual se enuncia a livre iniciativa.

13 De forma semelhante, André Ramos Tavares expōe que a livre de iniciativa no campo econômico é constituída pelas liberdades de trabalho, de empreender, conjugada com a de associaçăo, tendo como pressuposto - entre outros elencados pelo autor - a liberdade de contrato. (2011, p. 237.). IDENTIFICAR GRIFOS, SE DO AUTOR, SE DO ARTICULISTA.

14 Cf.: nota de rodapé $n .{ }^{\circ} 5$.

15 Conforme ressalta Modesto Souza Barros Carvalhosa, quando aduz que a livre iniciativa encontra limitaçōes extrínsecas, uma vez que coexiste com as diversas esferas de interesses tutelados pelo ordenamento jurídico. (1972, p. 115.).

$16 \quad$ Art. $5 .^{\circ}[\ldots]$

XVII - é plena a liberdade de associaçăo para fins lícitos, vedada a de caráter paramilitar;

XVIII - a criaçâo de associaçóes e, na forma da lei, a de cooperativas independem de autorizaçấo, sendo vedada a interferência estatal em seu funcionamento;

XIX - as associaçóes só poderăo ser compulsoriamente dissolvidas ou ter suas atividades suspensas por decisăo judicial, exigindo-se, no primeiro caso, o trânsito em julgado;

XX - ninguém poderá ser compelido a associar-se ou a permanecer associado;

$[\ldots]$. 
alcançar seus fins. Portanto, enquanto liberdade de meio, ${ }^{17}$ o direito à livre avença contratual é constitucionalmente assegurado (REALE, 1997, p. 7).

Por fim, tem-se o direito fundamental à liberdade de açăo profissional - expresso no artigo 5o, XIII ${ }^{18}$ da Constituiçấo Federal -, o qual protege o livre exercício de qualquer trabalho, ofício ou profissăo, observadas as qualificaçôes técnicas previstas pelo ordenamento jurídico. Segundo Celso Ribeiro Bastos (1999, p. 202.), essa possibilidade de escolha profissional relaciona-se nâo somente à livre iniciativa, mas também à liberdade humana - situando-se, portanto, na encruzilhada entre essas duas vertentes fundamentais -, competindo ao sujeito estabelecer o sentido à sua vida, ou seja, constituir o alicerce de sua própria personalidade, sendo o trabalho de importância substancial para tanto. Deve, pois, prevalecer a livre eleiçăo do ofício a ser exercido.

\subsection{Da natureza jurídica de direito fundamental}

Aliando-se ao conceito formulado por Dimitri Dimoulis e Leonardo Martins, os direitos fundamentais săo prerrogativas público-subjetivos de pessoas - físicas ou jurídicas -, contidos em dispositivos constitucionais e que, por isso, possuem caráter normativo supremo dentro do Estado (DIMOULIS; MARTINS, 2014, p. 41). Em outras palavras, săo direitos nomeados no instrumento constitucional e, por consequência, gozam de maior grau de garantia ou de segurança, posto que têm mudança dificultada - somente por meio de emenda à Constituiçâao. ${ }^{19}$

Considerando-se a atribuiçăo de posiçāo jurídica de direito subjetivo ao indivíduo - e a consequente limitaçấo do poder estatal - a principal finalidade dos direitos fundamentais (DIMOULIS; MARTINS, 2014, p. 49), estes podem ser classificados segundo suas correlatas funçôes: (i) de status negativo, ou de abstençâo do Estado; (ii) de status positivo, ou a prestaçóes pelo Poder Público; ${ }^{20}$ e (iii) de status activus ou de participa-

17 Miguel Reale, ao conceituar a livre iniciativa como projeçăo da liberdade individual no campo econômico, afirma que tal liberdade engloba nâo apenas a autonomia em relaçăo escolha da profissăo e das atividades econômicas a serem exercidas, como também a eleiçâo dos meios que o indivíduo julga serem adequados à realizaçáo dos seus fins. Ou seja, a livre iniciativa deve ser composta da plena liberdade do ser em relaçáo à escolha dos fins e dos meios, e nestes - conforme a concepçáo desta pesquisa -, encontra-se o contrato. (REALE apud PETTER, 2013, pp. 55-56.). IDENTIFICAR GRIFOS, SE DO AUTOR, SE DO ARTICULISTA

18 Art. 5. $^{\circ}[\ldots]$

XIII - é livre o exercício de qualquer trabalho, ofício ou profissāo, atendidas as qualificaçōes profissionais que a lei estabelecer;

[...].

19 Caracterizaçâo dada por Carl Schmitt, a partir de critérios formais definidores dos direitos fundamentais. (BONAVIDES, 2004. p. 561.) Adota-se, portanto, o elemento da fundamentalidade formal, segundo o qual um direito é fundamental se for garantido mediante normas de força jurídica advinda da supremacia constitucional, conforme grassam Dimitri Dimoulis e Leonardo Martins. (2014, p. 41.). Cabe observar que nâo se pode confundir essa condiçâo formal - a qual póe em consideraçâo a supremacia da constituiçăo - com a alegaçấo de que todos os direitos fundamentais estấo previstos, taxativamente, no Título II da Constituiçâo de 1988, pois tal Carta Magna adota a concepçăo material (art. $5 .^{\circ}, \S 2^{\circ} .^{\circ}$ ) desses direitos, os quais podem ser formais - necessariamente, pois devem estar contidos no texto normativo da Lei Maior - e materialmente constitucionais - no sentido de nâo estarem previsto no rol elencado no Título II, mas que, por seu conteúdo e importância sâo também fundamentais. Em relaçâo à tal problemática, tem-se os ensinamentos de Ingo Wolfgang Sarlet (2007, p. 95.) e do autor J. J. Gomes Canotilho (2011, pp. 404-407.). IDENTIFICAR GRIFOS, SE DO AUTOR, SE DO ARTICULISTA

20 Utilizou-se a expressăo Poder Público para designar o mesmo significado de Estado. 
çăo nos processos decisórios da política (GEORG JELLINEK apud DIMOULIS; MARTINS, 2014, pp. 50-54).

Torna-se pertinente, para esta pesquisa, os direitos de status negativo - liberdades públicas ou substanciais -, cuja funçâo é de defesa, conferindo, pois, um espaço subjetivo de distanciaçâo e autonomia ao indivíduo, com o correspondente dever de abstençâo ou proibiçâo de agressâo por parte do destinatário passivo ${ }^{21}$ - o Estado. ${ }^{22}$

Os direitos fundamentais de status libertatis negativus tutelam a autonomia individual - com correspondente obrigaçăo de năo intervençâo endereçada ao poder estatal - em várias esferas da açăo humana, dentre elas a econômica ${ }^{23}$ - englobando nâo só a liberdade de empreender, como também a de contrato, uma vez que esta é necessária ao exercício daquela, conforme supracitado -, a profissional - que compreende a escolha e exercício do trabalho - e a de expressáo coletiva - a qual abrange a livre associaçâo. ${ }^{24}$ Correspondem tais direitos, pois, às facetas constitucionais da livre iniciativa supracitadas.

Nâo podendo a liberdade econômica dos indivíduos ser violada sem restringir os direitos fundamentais consagradores dos corolários que a compóem, e constatando-se o seu desiderato de defesa da esfera jurídica dos cidadâos perante o Estado, ou seja, a presença do status negativo ${ }^{25}$ da livre iniciativa, conclui-se que esta é năo só um fundamento da Ordem Econômica, mas, também, um direito fundamental formalmente constitucional fora do catálogo (CANOTILHO, 2011, pp. 404-405.) do Título II ${ }^{26}$ da nossa Carta Magna.

21 Conceito dado por J. J. Gomes Canotilho em relaçáo à categoria direitos, liberdades e garantias, correspondente aos direitos fundamentais de status negativo da tripartiçáo elaborada por Georg Jellinek. (2011, p. 401.).

22 Os direitos fundamentais correspondem a deveres do Estado - de abstençáo ou negativos, e de prestaçâo ou positivos. Em outras palavras, vinculam diretamente o Poder Público. Mas, além desses deveres, há também o de proteger os indivíduos contra agressôes oriundas de terceiros - trata-se da eficácia horizontal dos direitos fundamentais. Estes, portanto, năo vinculam de forma direta os particulares, mas indiretamente, sendo competência estatal proteger a esfera de liberdade humana contra interferências alheias. (DIMOULIS; MARTINS, 2014, p. 102.). IDENTIFICAR GRIFOS, SE DO AUTOR, SE DO ARTICULISTA

23 Corroborando com essa noçâo, Leonardo Martins expōe que os direitos fundamentais, enquanto normas dotadas de supremacia no Estado Constitucional e democrático de direito, respondem a questōes de ordem macropolíticas - aqui encontram-se a maioria das prerrogativas público-subjetivas - e macroeconômicas, a depender da área regulamentada. (2012. pp. 159-160.) IDENTIFICAR GRIFOS, SE DO AUTOR, SE DO ARTICULISTA.

24 Tais esferas elencadas, onde deve prevalecer a autonomia individual, foram expostas conforme os cinco grandes grupos de liberdade distinguidos por José Afonso da Silva. (SILVA, J. A. da., 2005, p. 235.).

25 Constataçôes feitas a partir do quadro metódico elaborado por J. J. Gomes Canotilho, no qual o autor expóe alguns critérios para identificar um direito fundamental formalmente constitucional fora do catálogo. (CANOTILHO, 2011, pp. 405-406.). IDENTIFICAR GRIFOS, SE DO AUTOR, SE DO ARTICULISTA

26 Coadunando com as ideias apresentadas, tem-se Modesto de Souza Barros Carvalhosa (1972, pp. 112-113.), Lafayete Josué Petter. (2008, pp. 179-180.) e Marcelo Lauar Leite (2013, pp. 11-13.). Nesse sentido, veja-se o seguinte julgado: "CONTRATO BANCÁRIO. Açáo declaratória visando obrigar o Banco à baixa de uma restriçăo cadastral interna para efeitos de viabilizar futuras operaçôes de crédito. Inadmissibilidade. Impossibilidade de ingerência na liberdade interna da empresa, pois a Constituiçâo Federal (art. 170) assegura a livre iniciativa, portanto consagrando o direito à năo intromissăo do Estado. Recurso năo provido. A livre iniciativa econômica se insere como direito fundamental, donde náo é possível a pretendida ingerência ou intromissấo do Estado nas decisóes internas das empresas privadas". (TJSP, Apelaçáo n. 4005159-62.2013.8.26.0562, Relator: Gilberto dos Santos, Décima Primeira Câmara de Direito Privado, Publicaçăo: DJ em 24-07-2014. Grifo nosso). 


\section{OS LIMITES DA RESTRIÇÃO ESTATAL À UM DIREITO FUNDAMENTAL}

Enquanto liberdade jurídica manifestada em uma sociedade organizada (BADENI, 2004, p. 324.) - e, portanto, parte de um ordenamento guardiăo de outros interesses -, a livre iniciativa encontra-se controlada pelo Estado, seja por limitaçóes diretamente constitucionais - algumas das quais preveem o papel indicativo do Poder Público como agente normativo e regulador da atividade econômica ${ }^{27}$ - ou autorizadas pela Constituiçâo - por meio de reserva legal ${ }^{28}$-, que permitem, pois, uma justificaçâo constitucional da intervençăo na área de proteçâo de direito fundamental (DIMOULIS; MARTINS, 2014, pp. 148-149.).

Contudo, tal caráter relativo năo é absoluto, no sentido de nâo ser permitido ao Estado intervir ilimitadamente na livre iniciativa, uma vez que toda restriçâo há de passar pelo exame da proporcionalidade ${ }^{29}$ - pelo qual se averiguará a adequaçâo, a necessidade e a proporcionalidade em sentido estrito (ÁVILA, 2005, pp. 112-113.) da limitaçăo infraconstitucional ${ }^{30}$-, ou da ponderaçâo - em caso de colisăo entre princípios potencialmente aplicáveis na resoluçâo do caso concreto - para que seja considerada uma intervençâo fundamentada constitucionalmente. Uma restriçăo nâo proporcional - ou, em caso de colisăo de princípios, que năo seja resultante do método de sopesamento ${ }^{31}$ - a um direito fundamental, fere o conteúdo essencial deste, sendo, pois, uma violaçấo estatal.

\subsection{0 suporte fático, o conteúdo essencial e o postulado da proporcionalidade}

Antes de investigar em quais hipóteses o Estado pode ou nâo restringir a liberdade de iniciativa, cabe esclarecimentos conceituais acerca dos componentes do tipo normativo - ou suporte fático - de um direito fundamental, visto que, apenas com

27 Tem-se como exemplos o artigo 174. da Constituiçấo Federal, que prevê: “Como agente normativo e regulador da atividade econômica, o Estado exercerá, na forma da lei, as funçôes de fiscalizaçâo, incentivo e planejamento, sendo este determinante para o setor público e indicativo para o setor privado." (Grifo nosso); e o artigo $173, \S 4 .^{\circ}$, que, por sua vez, expressa: “A lei reprimirá o abuso do poder econômico que vise à dominaçấo dos mercados, à eliminaçáo da concorrência e ao aumento arbitrário dos lucros." (Grifo nosso).

28 Robert Alexy ensina que os direitos fundamentais somente podem ser restringidos por normas de hierarquia constitucional ou em virtude delas. Dessa forma, as restriçóes de hierarquia constitucional sâo diretamente constitucionais, já as limitaçôes infraconstitucionais sâo indiretamente constitucionais - visto que estas devem ser autorizadas por normas constitucionais mediante reserva legal. (2008. p. 286.). IDENTIFICAR GRIFOS, SE DO AUTOR, SE DO ARTICULISTA.

29 Dimitri Dimoulis e Leonardo Martins ao perceberem a dificuldade prática de saber em que consiste o conteúdo essencial de um direito fundamental - e, portanto, o limite da restriçáo estatal -, afirma ser o critério da proporcionalidade o meio pelo qual se analisa a constitucionalidade das limitaçóes impostas. Conforme as palavras dos autores supracitados: “[...] deve ser examinada a relaçăo entre os meios interventivos e os fins que o Estado persegue com a intervençâo, ou seja, deve ser analisada (e, antes disso, definida) a necessidade de cada intervençáo.". (2014, pp. 168-169.). Nesse sentido, há ampla coadunaçâo de doutrina constitucional, representados por Virgílio Afonso da Silva (2006. p. 43.), Bernardo Gonçalves Alfredo Fernandes (2014, pp. 337-339.), Paulo Bonavides (2009, p. 395.) e Robert Alexy (2008, p. 301.).

30 Leis ordinárias, decretos, portarias e até mesmo sentenças judiciais.

31 Os termos ponderaçâo e sopesamento serâo utilizados, ao longo deste trabalho, como sinônimos. 
uma clara compreensăo da estrutura deste, é possível falar em garantia constitucional frente ao poder estatal. ${ }^{32}$

De acordo com Virgílio Afonso da Silva (2006, p. 31), o suporte fático é constituído por elementos que, quando preenchidos, dāo ensejo à realizaçâo do preceito da norma de direito fundamental - ou seja, verificado o tipo normativo, há consequência jurídica. Visto a identificaçăo desses componentes ser uma tarefa difícil, o autor indica algumas perguntas para auxiliar no entendimento do que vem a ser suporte fático: (i) o que é protegido pela norma fundamental? - ou o que faz parte do seu âmbito de proteçâo?; (ii) contra o que se protege o bem jurídico?; (iii) qual é a consequência jurídica em caso de violaçâo ao conteúdo protegido?; e (iv) o que é necessário para que ocorra a consequência? (2006, p. 29). O tipo normativo de um direito fundamental é, pois, a junçâo de todas as respostas dadas às questōes citadas, conforme será visto adiante.

Filiando-se às teorias de suporte fático amplo, pode-se afirmar que todo e qualquer fato, estado, açâo ou posiçâo jurídica, que, considerado isoladamente, é característico ao âmbito de proteçâo de uma norma de direito fundamental, deve ser, ao menos inicialmente, considerado protegido - independentemente da análise de qualquer outro critério fático ou jurídico que obste à proteçâo de condutas ou situaçôes. ${ }^{33} \mathrm{~A}$ decorrência jurídica da adoçâo desse conceito amplo é o da necessária fundamentaçâo de toda e qualquer restriçâo - intervençâo, regulamentaçăo ou regulaçăo ${ }^{34}$-, năo sendo suficiente, pois, a mera indicaçăo de limites imanentes à própria norma. ${ }^{35}$ Exige-se, dessa forma, maior ônus argumentativo do agente restritivo, impondo a este a obrigaçáo de fundamentar o ato interventivo através do postulado da proporcionalidade, ${ }^{36}$ pelo qual se averigua o conteúdo essencial de um direito fundamental, e, consequentemente, se esse núcleo veio a ser casuisticamente violado.

O comportamento, estado ou posiçáo jurídica abrangidos pelo âmbito de proteçāo de um direito fundamental, sâo tutelados contra intervençóes - geralmente do Estado. A consequência jurídica em caso de violaçăo estatal a uma prerrogativa

32 Virgílio Afonso da Silva expôe que diversos autores, ao apontarem a definiçăo de suporte fático dos direitos fundamentais e a íntima relaçăo desse conceito com o de restriçăo estatal, indicam tal vínculo como uma construçáo fundamental na garantia constitucional da liberdade individual contra o poder estatal. Dessa forma, a compreensâo da estrutura normativa de um direito fundamental é de suma importância para entender, mais claramente, que espécies de restriçôes violam - ou năo - um direito fundamental. (SILVA, 2006, pp. 23-51.).

33 Conceito baseado nos ensinamentos de Virgílio Afonso da Silva (2006, pp. 34-35). Nessa passagem, há referências aos autores Martin Borowski, Wolfram Cremer, Dietrich Murswiek e Robert Alexy. Este conceitua a teoria do suporte fático amplo como aquela na qual se inclui no âmbito de proteçấo de um direito fundamental tudo que milite em favor de sua proteçấo. (ALEXY, 2008, p. 322.)

34 Os termos restrição, intervenção, regulamentação e regulação são empregados, neste trabalho, como sinônimos.

35 Em relação a isso, Virgílio Afonso da Silva expressou sua preocupação, quando afirmou que nas teorias nas quais o âmbito de proteção é restrito, "a restrição ocorre de forma disfarçada, com base em uma exclusão a priori de condutas, estados e posições jurídicas de qualquer proteção. [...] essas teorias, ao excluírem de antemão essa proteção, liberam o legislador e o aplicador do direito de qualquer ônus argumentativo." (2006, p. 49).

36 Vale lembrar que o exame do postulado da proporcionalidade ocorrerá quando se tratar de restriçâo por meio de regras, estas que geralmente sáo infraconstitucionais. Quando há uma intervençáo baseada em princípio, haverá a ponderaçâo entre dois princípios potencialmente aplicáveis ao caso concreto: 0 garantidor do direito fundamental e o outro a ser considerado pelo juiz em sua decisâo. (SILVA, 2014, pp. 141-143) 
público-subjetiva de um indivíduo é, pois, a cessaçăo da ingerência, pela declaraçăo da inconstitucionalidade do ato - seja ele legislativo, executivo ou judicial. Porém, náo basta a restriçâo realizada pelo Estado para que se configure a consequência jurídica:é preciso a nâo fundamentaçâo constitucional da intervençâo para esta ser considerada violadora de um direito fundamental.

Ora, há hipóteses nas quais a restriçăo estatal é fundamentada constitucionalmente, por meio do postulado da proporcionalidade - geralmente - náo afetando, pois, o conteúdo essencial do direito. Nesses casos, náo há o que se falar em violaçâo pelo Estado, e, por conseguinte, resta por năo preenchido o suporte fático da norma fundamental, nâo havendo, pois, a consequência jurídica.

Dessa forma, para a configuraçăo do suporte fático - e, assim, da consequência jurídica - é necessária a sua composiçâo pelo âmbito de proteçâo - qualquer fato, estado, açâo ou posiçâo jurídica relacionados ao bem jurídico protegido - pela intervençâo estatal e, por último, pela nâo fundamentaçâo. Portanto, se há uma conduta protegida pelo âmbito de proteçâo e uma restriçâo năo fundamentada, deve configurar-se a consequência jurídica - a declaraçáo de inconstitucionalidade e a consequente cessaçăo da violaçăo (2006, pp. 30-31).

Sintetizando essa relaçăo entre fundamentaçăo, proporcionalidade e conteúdo essencial e considerando que a maioria das limitaçôes advém de regras infraconstitucionais, Virgílio Afonso da Silva (2014, pp. 206-207) expóe o seguinte raciocínio silogístico:

restriçōes que atingem o conteúdo essencial săo inconstitucionais;

restriçôes que passem pelo teste da proporcionalidade sâo constitucionais;

restriçóes que passem pelo teste da proporcionalidade năo atingem o conteúdo essencial. (Grifos nossos)

Dessa forma, se uma intervençăo - no âmbito de proteçăo de um direito fundamental - năo é fundamentada constitucionalmente, ou seja, năo é adequada, necessária e proporcional em sentido estrito, fere o conteúdo essencial de uma prerrogativa público-subjetiva, impondo-se a cessaçăo da violaçâo estatal como consequência jurídica.

\subsection{Hipóteses de restriçâo permitidas e proibidas}

Com base nos conceitos de suporte fático, conteúdo essencial e proporcionalidade, analisados anteriormente, depreende-se que uma intervençâo em um direito fundamental pode ser uma restriçâo legítima, se fundamentada constitucionalmente, ou, caso contrário, uma violaçâo de uma prerrogativa público-subjetiva.

Isso posto, pode-se constatar que săo hipóteses de intervençăo permitidas os casos nos quais:

(i) há limitaçôes expressamente previstas na Carta Magna, contidas em preceitos que indicam o papel normativo e regulador do Estado na economia. ${ }^{37}$ Uma vez que a liberdade econômica náo é um fim em si mesma, mas uma garantia individual e instrumento de melhoria da qualidade de vida da sociedade, é de competência

37 Cf. nota de rodapé no 25. 
estatal o condicionamento de tal direito fundamental ao cumprimento de sua funçáo social. Dessa forma, através da defesa do livre mercado, bem como do estabelecimento de parâmetros para o exercício dessa liberdade, o Estado restringe a livre iniciativa com justificativa constitucional na sua funçăo de estabilizaçâo de interesses sociais (SILVEIRA NETO, 2013, pp. 132-134). Cabe a observaçâo de que os papéis estatais de fiscalizaçáo, incentivo e planejamento serăo exercidos na forma da lei. ${ }^{38}$ Há, portanto, reserva legal na hipótese de intervençăo em análise e, por esse motivo, trata-se de restriçâo indiretamente constitucional, ${ }^{39}$ ou seja, advinda da legislaçăo infraconstitucional, devendo passar pelo crivo da proporcionalidade;

(ii) existe limitaçâo diretamente constitucional, ${ }^{40}$ isto é, quando houver previsăo contida na própria redaçăo da norma de direito fundamental. Nesse caso, năo se trata de parte do suporte fático, ou de mera descriçáo do conteúdo que é protegido com suas condiçóes jurídicas - limites imanentes -, mas sim de cláusulas restritivas (ALEXY, 2008, p. 286.). Estas ocorrem quando o legislador constituinte estabelece uma restriçâo definitiva a direito fundamental e, dessa forma, já năo é mais necessário o exame de ponderaçâo, visto isso já ter ocorrido antes da consubstanciaçăo de tal decisăo restritiva. Tem-se como exemplo as cláusulas "para fins lícitos" e "vedada a de caráter paramilitar", as quais săo expressôes de restriçóes definitivas diretamente constitucionais ao direito fundamental à liberdade de associaçấo ${ }^{41}$. Ademais, é preciso ressaltar que essa năo proteçáo constitucional, advinda de decisăo do constituinte em favor de determinadas razóes, independe de como se individualize no caso concreto (ALEXY, 2008, pp. 286-288);

(iii) uma disposiçăo constitucional prevê garantia fundamental, mas com uma ressalva - ou reserva legal -, autorizadora da limitaçáo infraconstitucional aprovada pelo Poder Legislativo, desde que a lei năo afronte as normas da Carta Magna. Săo as chamadas restriçóes indiretamente constitucionais permitidas por meio de cláusulas de reserva expressas (ALEXY, 2008, p. 291). É imperioso destacar a adoçăo da acepçáo formal ${ }^{42}$ do termo lei quando este é utilizado pela Constituiçăo para autorizar limitaçăo à direito fundamental. Portanto, havendo tal reserva parlamentar, năo é possível a intervençăo realizada mediante normas inferiores - como decretos, portarias, sentenças etc. - se năo existe uma lei disciplinadora. Por fim, há de se notar, novamente, o necessário exame de proporcionalidade em relaçăo à restriçăo de direito fundamental baseada em regra de legislaçâo ordinária ou complementar;

(iv) em razăo da abstraçăo da norma, é preciso concretizaçâo mediante lei infraconstitucional. Esta que indicará o conteúdo e funçâo do direito fundamental constitucionalmente previsto (DIMOULIS; MARTINS, 2014, p. 152). Săo as restriçóes indiretamente constitucionais autorizadas por meio de cláusulas de reserva implícitas - na medida em que é necessária lei

38 Cf. nota de rodapé no 25.

39 Cf. nota de rodapé no 26.

40 Cf. nota de rodapé no 26.

41 Cf. nota de rodapé no 14.

42 Em relaçấo a isso, Dimitri Dimoulis e Leonardo Martins comentam que: "Historicamente, o constituinte autorizou a limitaçăo mediante lei em razăo das garantias democráticas, que oferecia uma medida tomada pelo Parlamento, na sua funçáo de principal órgăo de representação popular (publicidade, debate, vontade da maioria dos representantes populares). (2014, p. 161). 
infraconstitucional para proteger o direito. Como exemplo, ${ }^{43}$ tem-se o direito de propriedade, regulado pelo Código Civil, ${ }^{44}$ Estatuto da Terra, ${ }^{45}$ da Cidade ${ }^{46}$ etc. Na presente hipótese, também é preciso a fundamentaçăo constitucional de restriçấo de direito fundamental, por meio da proporcionalidade, visto a regulamentaçâo advir de legislaçăo infraconstitucional;

(v) há colisâo entre direitos fundamentais, ou há confronto entre uma prerrogativa público-subjetiva do indivíduo e um princípio de interesse geral (DIMOULIS; MARTINS, 2014, p. 150). É uma hipótese de restriçāo diretamente constitucional, na qual deve haver a ponderaçâo entre os potenciais princípios aplicáveis ao caso concreto; ${ }^{47}$

(vi) há graves conflitos ou ameaças à estabilidade da ordem política e social, isto é, em situaçóes excepcionais de decretaçăo do Estado de defesa ou do Estado de sítio (DIMOULIS; MARTINS, 2014, pp. 165-166). Trata-se de hipótese de restriçâo diretamente constitucional, na qual também é necessária a fundamentaçâo - por meio de ponderaçâo entre os princípios colidentes: o garantidor do direito fundamental e o de interesse geral que busca justificar a limitaçăo diante a calamidade concreta.

Em todas as hipóteses - à exceçăo apenas da elencada no item (ii) -, conforme foi explicitado, deve haver a fundamentaçâo constitucional, baseada ou no postulado da proporcionalidade - pelo qual se analisará se a restriçăo oriunda de regra infraconstitucional é adequada, necessária e proporcional em sentido estrito - ou na ponderaçâo de princípios colidentes - por meio da qual o juiz, no caso concreto, decidirá pelo interesse predominante.

Todos os casos năo previstos nas hipóteses anteriormente enumeradas, e além disso, nâo fundamentados constitucionalmente - seja por meio da proporcionalidade, ou da ponderaçâo de princípios - sâo inconstitucionais, e, consequentemente, violadores do núcleo essencial de um direito fundamental, devendo haver a consequência jurídica, qual seja, a cessaçâo da intervençâo ilegítima.

\section{CONSIDERAÇÕES FINAIS}

A livre iniciativa, enquanto poder dos indivíduos de criar e desenvolver uma atividade econômica - englobando as liberdades de empreendimento, associaçâo, contrato e açâo profissional - foi alçada à importância de fundamento ou razâo de ser da Ordem

\footnotetext{
$43 \quad$ Exemplo demonstrado por Marcelo Lauar Leite. (2014, p. 15).

44 Lei no 10.406, de 10 de janeiro de 2002.

$45 \quad$ Lei no 4.504, de 30 de novembro de 1964.

$46 \quad$ Lei no 10.257, de 10 de julho de 2001.

47 Conforme fora anteriormente destacado (Cf.: nota de rodapé n. ${ }^{\circ}$ 34), há casos em que a restriçăo năo será objeto de análise pela proporcionalidade, pois ainda năo há regra infraconstitucional disciplinadora da colisăo entre princípios. Nessas hipóteses - as quais ainda nâo tem decisăo legislativa constituída em norma - deve haver a ponderaçáo de potenciais princípios constitucionais - colidentes - aplicáveis ao caso concreto. A explicaçăo para a existência desse método é: se a aplicaçâo do postulado da proporcionalidade implica três perguntas - a medida é (i) adequada para fomentar o objetivo fixado? (ii) necessária? (iii) proporcional em sentido estrito? -, é preciso haver uma medida concreta a ser testada, o que náo ocorre em caso de colisâo entre princípios. (SILVA 2014, p. 179.).
} 
Econômica brasileira, conforme a Constituiçăo de 1988. Dessa forma, a livre iniciativa é elemento que condiciona a interpretaçăo jurídica de todas as normas constitucionais e infraconstitucionais.

Ademais, a livre iniciativa é, também, direito fundamental do indivíduo - de status libertatis negativus -, e, portanto, só pode ser restringida por normas de hierarquia constitucional ou em virtude destas - por meio de reserva legal. Além disso, a intervençâo deve ser fundamentada através da proporcionalidade - em caso de restriçâo por lei infraconstitucional - ou da ponderaçâo - quando se tratar de princípios colidentes. Caso contrário, năo havendo tal justificaçăo, há violaçâo ao conteúdo essencial do direito fundamental e, portanto, o ato interventivo é inconstitucional. 


\section{REFERÊNCIAS BIBLIOGRÁFICAS}

ALEXY, Robert. Teoria dos direitos fundamentais. Traduçâo: Virgílio Afonso da Silva. Săo Paulo: Malheiros, 2008.

AMARAL NETO, Francisco dos Santos. A liberdade de iniciativa econômica: fundamento, natureza e garantia constitucional. Revista de Informaçăo Legislativa, v. 23, n. 92, pp. 221-240, out.-dez. Brasília, 1986.

ÁVILA, Humberto. Teoria dos princípios: da definiçăo à aplicaçăo dos princípios jurídicos. 4. ed. Săo Paulo: Malheiros, 2005.

BADENI, Gregorio. Tratado de Derecho Constitucional. Buenos Aires: La Ley, 2004.

BARROSO, Luís Roberto. A ordem econômica constitucional e os limites à atuaçáo estatal no controle de preços. In: Janeiro: Renovar, 2009. . (Org.). Temas de direito constitucional II, 2. ed. Rio de

BASTOS, Celso Ribeiro. Curso de direito constitucional. 20. ed. Săo Paulo: Saraiva, 1999. BOBBIO, Norberto. Teoria da norma jurídica. Traduzido: Fernando Baptista; Ariani Bueno Sudatti. 3. ed. Săo Paulo: EDIPRO, 2005.

. Teoria do ordenamento jurídico. 6. ed. Traduzido: Maria Celeste C. J. Santos. Revisăo Técnica: Cláudio De Cicco. Brasília: Universidade de Brasília, 1995.

BONAVIDES, Paulo. Curso de direito constitucional. 15. ed. Sáo Paulo: Malheiros, 2009. CANOTILHO, J. J. Gomes. Direito constitucional e teoria da constituiçăo. 7. ed. Coimbra: Almedina, 2011.

CARVALHOSA, Modesto Souza Barros. A ordem econômica na Constituiçăo de 1969. Revista dos Tribunais, Săo Paulo, 1972.

DIMOULIS, Dimitri; MARTINS, Leonardo. Teoria geral dos direitos fundamentais. 5. ed. Săo Paulo: Atlas, 2014.

FERNANDES, Bernardo Gonçalves Alfredo. Curso de direito constitucional. 6. ed. Salvador: JusPodivm, 2014.

GRAU, Eros Roberto. A ordem econômica na Constituiçăo de 1988. 16. ed. Săo Paulo: Malheiros, 2014.

LEITE, Marcelo Lauar. Descortinando um direito fundamental: notas sobre a liberdade de iniciativa. Revista Digital Constituiçăo e Garantia de Direitos, v. 06, n. 02, 2013.

. Uso năo comercial do objeto ou pedido de patente pelo estado brasileiro: críticas ao P.L. n. ${ }^{\circ}$ 5.407/13. Coimbra: Institvto Ivridico da Faculdade de Direito da Universidade de Coimbra, 2014.

LOPEZ, Teresa Ancona. Princípios contratuais. In: FERNANDES, Wanderley. (Org.). Contratos empresariais: fundamentos e princípios dos contratos empresariais. Sâo Paulo: Saraiva, 2007. Série GVlaw. 
MARTINS, Leonardo. Liberdade e Estado Constitucional: leitura jurídico-dogmática de uma complexa relaçăo a partir da teoria liberal dos direitos fundamentais. Săo Paulo: Atlas, 2012.

MARTINS FILHO; SILVA, Ives Gandra da. Direitos fundamentais. In: ; et al. (Orgs.). Tratado de direito constitucional I. Sáo Paulo: Saraiva, 2010.

MASSÉ, Gabriel. Le Droit Commercial. Dans ses rapports avec le droit des gens et le droit civil. Livre I. 2. éd. Paris: Guillaumin et C. ie Libraries, 1861.

PETTER, Lafayete Josué. Direito econômico. 6. ed. Porto Alegre: Verbo Jurídico, 2013.

Princípios constitucionais da ordem econômica: o significado e o alcance do artigo $\overline{170}$ da Constituiçâo Federal. 2. ed. Sáo Paulo: Revista dos Tribunais, 2008

REALE, Miguel. Questōes de direito privado. Sāo Paulo: Saraiva, 1997.

SARLET, Ingo Wolfgang. A eficácia dos direitos fundamentais. 7. ed. Porto Alegre: Livraria do Advogado Ed., 2007.

SARMENTO, Daniel. Os princípios constitucionais da liberdade e da autonomia privada. In: GUERRA, Isabella Franco; PEIXINHO, Manuel Messias; NASCIMENTO FILHO, Firly. (Org.). Os Princípios da Constituiçăo de 1988. 2.bed. Rio de Janeiro: Lumen Juris, 2006.

SILVA, José Afonso da. Curso de direito constitucional positivo. 25. ed. Săo Paulo: Malheiros, 2005.

SILVA, Virgílio Afonso da. Direitos fundamentais: conteúdo essencial, restriçóes e eficácia. 2. ed. São Paulo: Malheiros, 2014.

O conteúdo essencial dos direitos fundamentais e a eficácia das normas constitucionais. Revista de Direito do Estado, Rio de Janeiro, v. 4, p. 23-51, 2006.

SILVEIRA NETO, Otacílio dos Santos. A livre concorrência e a livre-iniciativa como instrumentos de promoçâo do desenvolvimento - A funçăo estabilizadora da intervençâo do Estado no domínio econômico. Revista de Direito Público da Economia, Belo Horizonte, v. 42, p. 123-139, 2013.

TAVARES, André Ramos. Direito constitucional econômico. 3. ed. Rio de Janeiro: Forense; Sâo Paulo: Método, 2011. 